\title{
RIGHTS AND DUTIES OF PUBLIC SERVICE CORPORATIONS
}

\author{
By Hon. J. B. Whitfield, Chief Justice of Florida.
}

Corporations that are organized for the purpose of furnishing useful facilities and accommodations to the public, as to which the right of governmental supervision and regulation exists, are sometimes denominated quasi-public corporations, and are generally known as public utilities or public service corporations. This class includes corporations engaged in operating railroads, street cars, boats, wharves, elevators, ferries, telegraph and telephone lines, waterworks, gas and electric light plants and other similar facilities for the accommodation of the public.

The rights and privileges of corporations are such only as are allowed by express or implied provisions of law, which are usually contained in charters or in statutes or municipal ordinances.

A right of a corporation to the exercise or use of a franchise privilege is distinct from its right to exist as a corporate entity. One governmental authority may legalize the formation of a corporation with a right to use franchises if such use is granted or permitted by another governmental authority possessing or controlling the franchises.

In addition to the right to exist as corporate beings, public utility corporations are by governmental authority permitted to use franchises that belong to the public. These franchises are authority to have and exercise privileges that cannot be had and exercised of common right, such as authority to be a common carrier, to furnish stated accommodations to the public, to use the public highways, to exercise the right of eminent domain, and to exact and summarily enforce the payment of reasonable compensation for service rendered. Franchises belong to the public and do not become the absolute property of persons or corporations. They are rights granted or permitted by governmental authority, primarily and essentially for the public welfare. Franchises are not consumed in the use; and the use of them, whether it is granted or permitted, may be forfeited or withdrawn for abuses when no private contract right is thereby impaired. 
For rights and privileges granted, the law imposes correlative duties and liabilities. In conferring upon corporations the privilege of combining resources for valid purposes, the law imposes a corresponding duty to so use the combination as not to abuse the privilege.

The duties of corporations may be expressed in charters, statutes, ordinances or other valid governmental regulations. But an express enumeration of all duties is impracticable, and those expressly prescribed are in general not exclusive of other duties. and correlative liabilities that arise by implication of law. Implied duties are as binding as those expressly imposed, and are much more numerous. Duties that are implied by the principles of the common law may be modified or superseded by valid express statutory authority.

The duties that arise by implication of law depend upon the circumstances of each case. The law imposes upon every one, including legal entities, the duty to so act in person or through agents as not to negligently, needlessly or unlawfully injure another. This applies to the use of property, the transaction of business, the pursuit of any vocation, the rendering of any service, and to every act or conduct.

All persons and corporations are by implication of law charged with duties commensurate with the nature, extent and requirements of the public service undertaken by them. In order to accomplish the chief purpose of rendering adequate service for reasonable compensation and without unjust discrinination, it is the implied duty of public service corporations to lawfully procure the use of, and in good faith to use, franchises, that may be granted or permitted to them by proper authority for use in the service to be rendered. It is also their duty to procure only suitable and necessary property at a fair value, for use in rendering the service; to secure and use only appropriate, competent and necessary. skill, management and labor, through officers, agents and other employees, for which only reasonable compensation should be paid; to make and maintain all suitable provisions. for the safety of employees and patrons and to meet the just requirements of the service undertaken; to anticipate with reasonable care and diligence the further demands of the serviceand prepare for it; to carefully preserve and conserve the property used in rendering the service; to provide for and to main- 
tain safe, careful, efficient and economical management of the business; to confine operations to the service authorized to be engaged in; to pay only reasonable and just compensation for management, labor and property used in rendering the service; to avoid any and all kinds of abuse in the conduct of the corporation; to refrain from unjust discriminations in rendering the service; to take all reasonable care in case of casualties, to prevent and alleviate personal suffering and to protect property without unjust discrimination; to improve the service as may be justly required to meet the demands of the public to be served; to use such appropriate appliances and facilities as are requisite to a proper rendering of the service undertaken; to charge only a reasonable compensation for service rendered; to pay all lawful. and just taxes and assessments; to observe all lawful governmental regulations of the service undertaken; to make just and prompt compensation for injuries to persons and property caused. by the negligence or breach of contract of its officers, agents and employees within the scope of their authority; and to obey and observe the laws of the land.

It is likewise the duty of public service corporations to resist all unlawful and unreasonable demands, whether as compensation for property, management or labor used in rendering the public service, or as invalid governmental regulations or exactions, or as unlawful and unreasonable demands as damages for its negligent torts or breaches of contract. This is a just requirement of the law, since, while it is a duty to meet all just and lawful demands, wrongful and unreasonable demands are an unlawful taking or deprivation of property rights, and the loss. thereby incurred by the corporation will result in excessive or unreasonable rates for the service rendered to the public or in an inadequate service to the public, either of which results is contrary to law and public policy and inimical to the general welfare.

The acquisition, holding or use of unnecessary or unsuitable property, or the employment of useless, inefficient or unsuitable management or labor, or the payment of excessive prices for appropriate and necessary property or labor for use in rendering the public service, is a violation of a duty to the State and to the public, in that it injuriously affects the service rendered or the compensation charged for such service. The reasonableness of rates charged should be based upon a consideration of the fair 
value of the skill, labor, management and property used in rendering the service, as well as of the character of the service, the time and risk required, the nature of the property and the efficiency of the labor used in performing the service, the volume of the business, and the conditions under which the service is rendered.

As a corporation, being merely a legal entity, cannot be born, or naturalized, it cannot be a citizen of the United States; and consequently, it has no privileges or immunities of a citizen that the States are forbidden by the Fourteenth Amendment to the Federal Constitution to abridge.

While corporations are not mentioned in the Federal Constitution, and are in fact not natural persons, they are regarded as legal persons having property rights that are safe-guarded by the supreme law of the land. The protection afforded to natural persons in their property rights by the Fourteenth Amendment to the Federal Constitution was intended to be complete and effective. Natural persons own all the property rights of corporations, and the organic guarantees that no person shall be deprived of property without due process of law, nor denied the equal protection of the laws, extend to property rights owned by natural persons though the legal title thereto is held and the control and management thereof be through the medium of a corporation. The intervention of the corporate entity as the holder of the title as authorized by law for purposes of industrial economy does not prevent the operation of the organic law in the protection of property rights. Whatever the law forbids to be directly done, it also forbids to be indirectly done; otherwise technical or subtle evasions would render the law impotent and futile for the purposes designed. Upon this theory, organic guarantees of private property rights are made applicable to corporations in their property rights.

In the Constitutions of most of the States, the property rights of corporations are expressly recognized, and the safe-guards designed for the protection of private property rights are applicable alike to natural persons and to corporations, since natural persons are the real owners of all private property rights, including those held by or through the medium of corporations.

A State may impose conditions and restrictions upon the rights and privileges of a corporation organized under its authority; 
and the rights and privileges of a corporation in a State other than that of its origin depend upon its charter and the local laws relative thereto, and upon comity and the laws of the other State. A corporation existing under the laws of the State is a foreign corporation as to other States; but a corporation authorized by Congress may not be a foreign corporation as to the several States of the Union.

Corporations are not citizens within the meaning of the provision of Section 2, Article IV, of the Constitution of the United States, that "the citizens of each State shall be entitled to all privileges and immunities of citizens in the several States", and a State may forbid to foreign corporations the privilege of doing business within its borders, or may impose conditions for the privilege, provided no applicable Federal law is thereby violated. It is the duty of the State to protect the lives and property within its limits, to prevent imposition and injustice, and to secure the safety, health and well being of all within its territory; and to this end it may regulate the entry and conduct of foreign corporations in the State, where such regulations are not in conflict with lawful Federal authority.

Utility corporations should not be regarded as public enemies. They exist and are operative under express authority of law, and are entitled to all the rights and privileges accorded to them by law. Self respecting and law-abiding individuals should concede to such corporations their lawful status and rights; but all persons should insist that public utility corporations, and their officers, agents and employees be required by proper procedure to observe the law in every particular, and to act with due regard for the rights of others in the faithful, impartial and proper performance of the public service which under the law is the primary purpose of the existence and operation of such corporations.

The rendering of public service by furnishing railroad, street car, telegraph, light, water and other useful facilities ordinarily requires large capital, efficient management, varied skill, great risks and continuous existence, that cannot with any degree of certainty be supplied by an individual. For this reason and in the interest of the public welfare the law authorizes the formation and operation of corporations, by means of which valid combinations of capital and other resources, and of skill, management and labor may be utilized, with limited persona! liability of 
stockholders and continuous existence in corporate authority, for the benefit of the public to be served.

While such corporations are owned, organized and operated in private right, subject to all applicable provisions of law for the protection of private property rights, yet the corporations and the property owned and controlled by them are, by virtue of the franchises and privileges accorded to them, and in consideration of the public service voluntarily undertaken to be performed, subject to the rights of the public affected by the service. These essential rights of the public are to require an adequate service to be performed for a reasonable compensation and without unjust discrimination of any character as to persons, localities, commodities or otherwise.

In accepting the franchise and engaging in the public service, such a corporation voluntarily subjects its property to the rights of the public. The public interest in such corporations includes the right to and the burden of lawful governmental regulation and supervision; therefore the burden of valid regulations is not a taking or a deprivation of property rights in violation of the organic law. But an unlawful or unreasonable regulation of any character that in effect deprives a corporation of a substantial property right, or imposes an unlawful or tnreasonable burden, is a violation of constitutional rights. The law does not permit confiscation or the imposition of unreasonable burdens, or even arbitrary control and management of public utility corporations and their property by governmental authority under the guise of authorized supervision and regulation.

The governmental authority to supervise and regulate the rendering of public service by corporations extends to every phase of the corporate activities that affects the service to be regulated. Whether regulations duly promulgated by competent authority relate to rates or to the rendering of the service, such regulations should be regarded as prima facie reasonable and just, and their enforcement should not be enjoined by the courts unless it clearly appears, from the admissions of pleadings or from proofs, that such enforcement will inevitably deprive the corporation of its property rights in violation of law.

When authority to prescribe regulations appears, a wide discretion should be accorded to the governmental agency in administering regulations; and where, after a fair consideration of all 
the facts and circumstances affecting a regulation, it appears that reasonable men competent to judge may differ as to whether the regulation is reasonable and just, the regulation duly prescribed should be put to the test of a fair experiment.

But governmental agencies may impose regulations only within their lawful authority; and such agencies should act only after a fair consideration of all the facts and circumstances affecting the action taken. Where action is taken arbitrarily and without the existence of facts and circumstances to support it, the action is the ipse dixit of the agency without authority of law, and not the action of the government under the law. The law authorizes regulations to be enforced when they are duly promulgated by competent authority and are based upon appropriate facts warranting the regulations. The mandate of the law operates upon sufficient facts duly ascertained, and not upon the personal desire of individuals.

An essential duty of a corporation is to make compensation in damages for injuries to persons and property caused by the negligence of its employees in discharging their duties as such. Where property is injured or destroyed, its value can generally be readily ascertained; but in cases of personal injury, the amount of compensation properly recoverable therefor should be ascertained by a fair consideration of all the pertinent facts and circumstances affecting both parties, and the application of the processes and standards of reasoning and computation that are afforded by law, or by common experience and the dictates of right and justice. Recovery of just demands should be promptly enforced, and corporate advantages should be held in proper check by use of the procedure afforded by the law for this purpose.

A recovery of damages not allowed by law may be remedied by ordinary appellate procedure. But where damages are lawfully recoverable and the amount awarded by a verdict or finding is either inadequate or excessive, the only remedy afforded by the common law is an application to the trial judge for a new trial because of the inadequacy or excessiveness of the verdict. The trial court should grant a new trial where there is difficulty in reconciling the verdict with the justice of the case and the manifest weight of the evidence.

At common law the Appellate Court could not grant a new trial merely because a verdict is inadequate or excessive in amount, 
unless some rule of law was thereby violated, since questions of fact were not reviewable by the Appellate Court at common law. This is now the rule in the United States Courts, because of the effect of the Seventh Amendment to the Federal Constitution, which provides that "In suits at common law $* * *$ the right of trial by jury shall be preserved, and no fact tried by a jury, shall be otherwise re-examined in any court of the United States, than according to the rules of the common law." The constitutions and statutes of many of the States make provision for the Appellate Courts to review the finding and to pass upon the sufficiency or excessiveness, as matter of law, of the amount awarded by a verdict in a trial court.

Even under such provisions, the Appellate Court will not as a rule reverse a judgment for inadequate or excessive damages, where the amount cannot be ascertained by defmite standards of compensation, unless the award is so small or so large as to shock the judicial conscience, or as to indicate that the finding has no reasonable support in the evidence. In considering this question, all the evidence adduced at the trial must be properly before the Appellate Court duly certified by the trial judge.

The property of corporations should be taxed as other property is taxed, and the same organic guarantees against unjust exactions are in general applicable to all property, whether corporate or individual, that is subject to taxation. Assessments should be made upon a basis having a just relation to fair valuation, considered with other property values for assessment purposes. As the government confers upon corporations the right to exist and to transact business, a privilege tax may be exacted in return' for the granted right conferring the advantages of corporate existence and operations. But such taxes should have some fair relation to the privileges conferred and to similar taxes imposed upon others under like conditions, and they should not be unduly onerous, since all taxes are to be considered in fixing reasonable rates for any public service rendered.

When municipal corporations undertake to render the service of a public utility or public service corporation, it does so in its corporate capacity, as distinguished from its governmental capacity; and unless otherwise provided by law, its duties and liabilities are similar to those of other corporations that perform a like service. 
Where the business undertaken by a public service corporation is not inherently unprofitable, and its purposes are in good faith carried out, and its operations are conducted as contemplated by law, proper governmental regulation and supervision should contribute to the stability of the corporate earnings and give confidence to investors by insuring a steady return for property and labor devoted to the service.

Public service corporations are by law allowed a wide primary discretion in rendering the public service undertaken; but such discretion must be exercised in obedience to law and in good faith and with due regard for the rights of the public; and the discretion is subject to lawful governmental supervision and regulation, to the end that the public may be properly served and private rights made secure by due course of law.

The guiding star and controlling purpose should ever be to secure to the public the primary right to a reasonably adequate service for a fair compensation and without unjust discrimination as to patrons or service, and to preserve to the corporations their absolute right to reasonable compensation for service rendered and to security against being deprived of their property or of its use in violation of law.

All steps taken are to be governed by applicable principles of the common law except where express enactments provide a different regulation in particular instances.

The common law is a progressive system of rules by which the principles of reason and justice are administered in controversies between adversary parties. The glory of the common law is its adaptability to every phase of human affairs and its efficiency in the administration of practical justice. In the complex circumstances of material and social development, the principles of law should be so applied as to preserve their vitality and merit as a progressive science of real benefit to mankind. Otherwise, the law will degenerate into a useless formula and thereby become a burden rather than an aid to civilization and human progress. This caution is particularly necessary in the exercise of governmental supervision and regulation of public service corporations whose operations so vitally and universally affect the daily life of substantially all the people. 


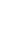

